\title{
Pengaruh Model Pembelajaran Contextual Teaching and Learning terhadap Kemampuan Komunikasi Matematis berdasarkan Pengetahuan Awal Siswa Madrasah Tsanawiyah
}

\author{
Amalia Firmansyah, Hasanuddin, dan Zulkifli Nelson \\ Program Studi Pendidikan Matematika, Universitas Islam Negeri Sulthan Syarif Kasim Riau \\ Jl. H. R. Soebrantas KM. 15.5, Pekanbaru, Indonesia. 29283 \\ e-mail: amaliafiramansyah26@gmail.com
}

\begin{abstract}
ABSTRAK: Penelitian ini bertujuan untuk melihat pengaruh pembelajaran Contextual Teaching and Learning (CTL) terhadap kemampuan komunikasi matematis siswa. Penelitian ini merupakan penelitian quasi eksperimen yang bertujuan untuk menyelidiki hubungan sebab akibat dengan cara memberikan perlakuan pada salah satu kelas dan membandingkan hasilnya dengan salah satu kelas yang diberikan perlakuan yang berbeda. Subjek dalam penelitian ini adalah siswa kelas VII-1 TSPK dan VII-3 MTs Islamic Centre Al-Hidayah Kampar dan objek penelitian ini adalah pengaruh penerapan model pembelajaran CTL terhadap kemampuan komunikasi matematis siswa yang ditinjau dari pengetahuan awal siswa. Teknis analisis data yang digunakan yaitu anova dua arah. Instrumen yang digunakan adalah tes uraian untuk mengukur pengetahuan awal dan kemampuan komunikasi matematis siswa. Hasil penelitian menunjukkan bahwa terdapat pengaruh model pembelajaran CTL dengan terhadap kemampuan komunikasi matematis siswa, tetapi tidak terdapat interaksi antara model pembelajaran dan pengetahuan awal siswa terhadap peningkatan kemampuan komunikasi matematis siswa.
\end{abstract}

Kata kunci: Contextual Teaching and Learning, Kemampuan Komunikasi Matematis, Pengetahuan awal Matematis.

\section{PENDAHULUAN}

Pendidikan memegang peranan penting dalam menjamin kelangsungan hidup suatu negara dan bangsa. Hal ini dikarenakan hakikat pendidikan yaitu untuk mengembangkan potensi atau kemampuan manusia secara menyeluruh yang pelaksanaannya dilakukan dengan cara mengajarkan berbagai pengetahuan dan kecakapan yang dibutuhkan oleh manusia itu sendiri (Syah, 2004). Pendidikan tersebut memiliki kualitas sumber daya manusia yang akan meningkat karena munculnya ide-ide mutakhir yang menjadikan suatu negara menjadi maju.

Salah satu faktor penting dalam pembelajaran matematika yaitu kemampuan komunikasi matematis siswa. Faktanya kemampuan komunikasi matematis di Indonesia masih tergolong rendah. Hal ini di ketahui dari survey internasional The Trend International Mathematics and Science Study (TIMSS). Dari hasil survei internasional TIMSS pada tahun 2011, Indonesia berada di peringkat ke 38 dari 63 dalam pembelajaran matematika. Aspek yang dinilai dalam mtematika adalah pengetahuan tentang fakta, prosedur, konsep, penerapan pengetahuan dan pemahaman konsep. Menurut laporan hasil studi international 47\%. Jika dibandingkan dengan negara lain kemampuan Indonesia dalam menerjemahkan soal kedalam bahasa ide matematika diagram atau grafik ini masih berada dibawah rata-rata (TIMSS, 2011).

Sementara itu, hasil laporan Survei Programme for International Student Assesment (PISA) yang merupakan program organisasi kerjasama ekonomi dan pembangunan dunia (OECD) menunjukkan bahwa pada tahun 2009, prestasi siswa Indonesia berada pada posisi 68 dari 74 negara yang disurvei. Skor rata-rata kemampuan siswa di neara lainnya yaitu 496. Aspek yang 
dinilai dalam PISA adalah kemampuan pemahaman, pemecahan masalah, penalaran dan komunikasi (Gardenia, 2016)

Kemampuan komunikasi matematika masih tergolong rendah (Sefalianti,2014). Hal ini dapat dilihat dari ketika siswa diberikan kesempatan untuk bertanya siswa tidak bertanya, siswa lebih cenderung menghafal rumus dari pada memahaminya, siswa tidak mampu melakukan komunikasi antar siswa saat belajar kelompok. Beberapa fakta lapangan tersebut terlihat bahwa kemampuan komunikasi dalam pembelajaran matematika sangat rendah (Dewi, et.al., 2017). Kemudian penelitian yang di lakukan oleh Hanapi dkk. (2013), menemukan bahwa yang menjadi penyebab siswa kurang mampu mengkomunikasikan pengetahuan matematika ke dalam soal yakni kurangnya kreatifitas guru dalam menciptakan pembelajaran yang lebih menarik, penggunaan metode pembelajaran yang belum sesuai dengan apa yang diharapkan, tingkat kemampuan siswa dalam mengkomunikasikan matematika kedalam soal berbeda-beda. Sehingga siswa kurang tertarik dengan pembelajaran matematika yang mengakibatkan siswa sulit untuk mengkomunikasikan pengetahuannya dalam soal yang diberikan dan berdampak negatif pada hasil belajar (Hanapi, et.al.,2013). Penyebab utama rendahnya hasil belajar siswa adalah bahwa kurangnya minat siswa untuk belajar matematika dan kebanyakan siswa hanya bisa menyelesaikan soal yang serupa seperti yang dicontohkan guru. Sebagian siswa kurang tepat dalam menuliskan notasi, menyajikan materi dan menguraikan jawabannya dengan tidak runtut dan tidak jelas serta kesalahan dalam menuliskan prosedur pencarian nilai dalam matematika. Kemudian siswa cenderung pasif dalam pembelajaran dan tidak mampu menghubungkan antara apa yang mereka pelajari dengan bagaimana pengetahuan tersebut akan dipergunakan. Hal ini sangat erat hubungannya dengan kemampuan komunikasi matematis siswa, sehingga perlu adanya perbaikan dalam hal meningkatkan komunikasi matematis siswa. Mereka sangat butuh untuk memahami konsep-konsep yang berhubungan dengan kehidupan sehari-hari.

Salah satu model yang dapat digunakan untuk meningkatkan kemampuan komunikasi matematis siswa adalah menggunakan model pembelajaran CTL. Pembelajaran kontekstual CTL merupakan suatu proses pendidikan bertujuan memotivasi siswa untuk memahami makna materi pelajaran yang dipelajarinya dengan mengaitkan materi tersebut dengan konteks kehidupan mereka sehari-hari dengan tujuan untuk menemukan makna materi tersebut bagi kehidupannya dan menjadikannya dasar pembelajaran dengan kemampuan komunikasi matematis siswa.

Faktor lain yang juga menentukan keberhasilan siswa dalam menerima pelajaran adalah kemampuan awal. Pengetahuan awal siswa dapat melihat dan mengetahui sejauh mana siswa telah mengetahui materi yang telah disajikan. Hal tersebut ditegaskan dalam Depdiknas (2005) bahwa: "Pengetahuan awal siswa penting untuk diketahui guru sebelum ia mulai dengan pembelajarannya, karena dengan demikian dapat diketahui: a) apakah siswa telah mempunyai pengetahuan yang merupakan prasyarat untuk mengikuti pembelajaran; b) sejauh mana siswa telah mengetahui materi apa yang akan disajikan" (p. 7).

Lebih lanjut dikemukakan belajar akan lebih bermakna apabila materi yang dipelajari (hasil belajar berupa konsep atau prinsip) diasumsikan atau dihubungkan dengan pengetahuan yang telah dimiliki siswa dalam bentuk struktur kognitif berupa fakta-fakta, konsep-konsep dan generalisasi yang dipelajari atau diingat oleh siswa. Pembelajaran yang berorientasi pada pengetahuan awal akan memberikan dampak pada proses dan perolehan belajar yang memadai. Berdasarkan pendapat tersebut menjelaskan bahwa pengetahuan awal merupakan elemen esensial untuk menciptakan proses pembelajaran menjadi sesuatu yang bermakna. Berdasarkan uraian tersebut, peneliti melakukan penelitian tentang pengaruh Model Pembelajaran CTL terhadap kemampuan komunikasi matematis siswa ditinjau dari pengetahuan awal Siswa. 


\section{TINJAUAN LITERARTUR}

\section{Komunikasi Matematis}

Komunikasi adalah suatu proses penyampaiaan informasi dari pihak satu kepada pihak lain, baik secara langsung (tatap muka) atau tidak langsung (media). Komunikasi pada hakikatnya merupakan proses penyampaian pesan dari pengirim kepada penerima (Risnawati, 2008). Sedangkan, Abdulhak menyatakan bahwa komunikasi adalah sebagai proses penyampaian pesan dari pengirim pesan kepada penerima pesan melalui saluran tertentu untuk tujuan tertentu (Ansori, 2016). Sedangkan Book (1980) menyatakan bahwa komunikasi adalah suatu transaksi, proses simbiolik yang menghendaki orang-orang mengatur lingkungannya dengan 1) Membangun hubungan antar sesama manusia, 2) Pertukaran informasi, ide, keterampilan, dengan menggunakan simbol-simbol, gambar, dan sebagainya, 3) Untuk menguatkan sikap dan tingkah laku orang lain, dan 4) Serta berusaha mengubah sikap dan tingkah laku itu (Cangara, 2005).

Ketercapaian tujuan merupakan keberhasilan komunikasi. Elemen-elemen yang terlibat komunikasi diantaranya yaitu: 1) Komunikator, Komunikator merupakan sumber dan pengirim pesan. Kredibilitas komunikator yang membuat komunikasi percaya terhadap isi pesan sangat berpengaruh terhadap keberhasilan komunikasi, 2) Pesan yang disampaikan, Pesan harus memiliki daya tarik tersendiri, sesuai dengan kebutuhan penerima pesan, adanya kesamaan pengalaman tentang pesan, dan ada peran pesan dalam memenuhi kebutuhan penerima. 3) Komunikan (penerima pesan), Agar komunikasi berjalan lancar, komunikan harus mampu menafsirkan pesan, sadar bahwa pesan sesuai dengan kebutuhannya, dan harus ada perhatian terhadap pesan yang diterima. 4) Konteks, Komunikasi berlangsung dalam setting atau lingkungan tertentu. Lingkungan yang kondusif sangat mendukung keberhasilan komunikasi. 5) Sistem Penyampaian, Sistem penyampaian berkaitan dengan metode dan media. Metode dan media digunakan dalam proses komunikasi harus sesuai dengan kondisi atau karakter penerima pesan (Majid, 2008).

Komunikasi matematika adalah suatu aktifitas penyampaian dan atau penerimaan gagasan matematika dalam bahasa matematika baik secara tulisan maupun lisan. Komunikasi matematika juga dapat diartikan sebagai peristiwa dialog atau saling hubungan yang terjadi dilingkungan kelas, dimana terjadi pengalihan pesan. Pesan yang dialihkan berisi tentang materi matematika yang dipelajari siswa, misalnya berupa konsep, rumus, simbol, istilah, bahkan strategi penyelesaian suatu masalah (Mahmudi, 2009).

Berdasarkan uraian di atas komunikasi matematika tersebut dapat kita simpulkan bahwa komunikasi matematika adalah peristiwa dialog atau saling hubungan yang terjadi dilingkungan kelas, seperti aktifitas peserta didik mendengarkan, membaca, menulis, berbicara, merefleksikan dan mendemonstrasikan informasi-informasi yang mereka dapatkan dari proses pembelajaran matematika dan keterkaitan dengan dunia nyata atau dalam kehidupan sehari-hari.

Adapun indikator kemampuan komunikasi yaitu 1) Kemampuan menggambar (drawing), yaitu meliputi kemampuan siswa mengungkapkan ide-ide matematika kedalam bentuk gambar, diagram, grafik, tabel dan secara aljabar. 2) Kemampuan menulis (written text), yaitu berupa kemampuan memberikan penjelasan dan alasan secara matematika dengan bahasa yang benar dan mudah dipahami. Dan 3) Kemampuan ekspresi matemtika (mathematical expression), yaitu kemampuan membuat model matematika. (Cai, et.al., 1996).

\section{Model Pembelajaran Contextual Teaching and Learning}

Model Pembelajaran CTL adalah suatu proses pendidikan yang bertujuan membantu siswa melihat makna dalam bahan pelajaran yang mereka pelajari dengan cara menghubungkannya dengan konteks kehidupan mereka sehari-hari, yaitu dengan konteks lingkungan pribadinya, sosialnya, dan budayanya (Nurhadi, et. al. 2004). CTL adalah suatu strategi pembelajaran yang menekankan kepada proses keterlibatan siswa secara penuh untuk dapat menemukan materi yang 
dipelajari dan menghubungkannya dengan situasi kehidupan nyata sehingga mendorong siswa untuk dapat menerapkannya dalam kehidupan mereka (Sanjaya, 2010). CTL adalah konsep belajar yang membantu guru mengaitkan antara materi yang diajarkan dengan situasi dunia nyata siswa dan mendorong siswa membuat hubungan antara pengetahuan yang dimilikinya dengan penerapannya dalam kehidupan mereka sehari-hari, dengan melibatkan tujuh komponen utama pembelajaran konstektual, yakni: kontruktivisme (constructivism), bertanya (questioning), inkuiri (inquiry), masyarakat belajar (learning comunity), pemodelan (modeling), dan penilaian autentik (authentic assessment)(Trianto, 2009). Jadi Contextual Teaching and Learning adalah Suatu strategi pembelajaran dimana guru mengaitkan materi pelajaran dengan situasi kehidupan sehari-hari agar pelajaran lebih bermakna.

Ada tujuh prinsip pembelajaran CTL yang harus dikembangkan oleh guru, yaitu: 1) Kontruktivisme (Contructivism), Kontruktivisme merupakan landasan berfikir dalam CTL, yaitu bahwa pengetahuan dibangun oleh manusia sedikit demi sedikit yang hasilnya diperluas melalui konteks yang terbatas. Dalam CTL strategi untuk membelajarkan siswa menghubungkan antara setiap konsep dengan kenyataan merupakan unsur yang diutamakan dibandingkan dengan penekanan terhadap seberapa banyak pengetahuan yang harus di ingat oleh siswa. 2) Menemukan (Inquiry), Menemukan atau Inkuiri artinya proses pembelajaran didasarkan pada pencarian dan penemuan melalui proses berfikir secara sistematis. Pengetahuan bukanlah sejumlah fakta hasil dari mengingat, akan tetapi hasil dari proses menemukan sendiri. Berdasarkan hal tersebut dalam proses perencanaan, guru bukanlah mempersiapkan sejumlah materi yang harus dihafal, akan tetapi merancang pembelajaran yang memungkinkan siswa dapat menemukan sendiri materi yang harus dipahaminya. 3) Bertanya (Questioning), Belajar pada hakikatnya adalah bertanya dan menjawab pertanyaan. Bertanya dapat dipandang sebagai refleksi dan keingintahuan setiap individu, sedangkan menjawab pertanyaan mencerminkan kemampuan seseorang dalam berfikir. Guru tidak menyampaikan informasi begitu saja, akan tetapi memancing agar siswa dapat menemukan sendiri. Karena itu peran bertanya sangat penting, sebab melalui pertanyaan-pertanyn guru dapat membimbing dan mengarahkan siswa untuk menemukan setiap materi yang dipelajarinnya. 4) Masyarakat belajar (Learning Community), Penerapan masyarakat belajar dapat dilakukan dengan menerapkan pembelajaran melalui kelompok belajar. Siswa dibagi dalam kelompok-kelompok yang anggotanya bersifat heterogen, maupun dilihat dari kemampuan dan kecepatan belajarnya, maupun dari bakat dan minatnya. Biarkan dalam kelompoknya mereka saling membelajarkan, yang cepat belajar di dorong untuk membantu yang lambat belajar, yang memiliki kemampuan tertentu di dorong untuk menularkannya pada yang lain. 5) Pemodelan (Modeling), Pemodelan adalah proses pembelajaran dengan memperagakan sesuatu sebagai contoh yang dapat ditiru oleh setiap siswa. Misalnya, guru memberikan contoh bagaimana cara mencari untung dan rugi dalam materi aritmatika. Proses pemodelan ini tidak hanya terbatas dari guru saja, akan tetapi dapat juga guru memamfaatkan siswa yang di anggap memiliki kemampuan. Misalnya siswa yang pernah mendapat juara dalam membaca puisi dapat disuruh menampilkan kebolehannya didepan teman-temannya. 6) Refleksi (Reflection), Refleksi adalah proses pengendapan pengalaman yang telah dipelajari yang dilakukan dengan cara mengurutkan kembali kejadian - kejadian atau peristiwa pembelajaran yang telah diketahuinya. Melalui proses refleksi, pengalaman belajar itu akan dimasukkan dalam struktur kognitif siswa yang pada akhirnya akan menjadi bagian dari pengetahuan yang dimilikinya. 7) Penilaian sebenarnya (Authentic Assesment), Proses pembelajaran konvensional yang sering dilakukan guru disaat ini, biasanya ditekankan kepada perkembangan aspek intelektual, sehingga alat evaluasi yang digunakan terbatas pada penggunaan tes. Penguasaan materi siswa dapat diketahui dengan tes. Berdasarkan pembelajaran CTL, keberhasilan pembelajaran tidak hanya ditentukan oleh perkembangan kemampuan intelektual saja, akan tetapi perkembangan seluruh aspek. Oleh sebab itu penilaian keberhasilan tidak hanya ditentukan oleh aspek hasil belajar seperti hasil tes, akan tetapi juga proses belajar melalui penilaian nyata (Rusma, 2010). 
Langkah-langkah pembelajaran CTL adalah sebagai berikut: 1) Mengembangkan pemikiran siswa untuk melakukan kegiatan belajar lebih bermakna, apakah dengan cara bekerja sendiri, menemukan sendiri, dan mengkonstruksi sendiri pengetahuan dan keterampilan baru yang akan dimillikinya. 2) Melaksanakan sejauh mungkin kegiatan Inquiry untuk semua topik yang diajarkan. 3) Mengembangkan sifat ingin tahu siswa melalui memuncul-kan pertanyaan-pertanyaan. 4) Menciptakan masyarakat belajar, seperti melalui kegiatan kelompok diskusi, tanya jawab, dan lain sebagainya. 5) Menghadirkan model sebagai contoh pembelajaran, bisa melalui ilustrasi, model, bahkan media yang sebenarnya. 6) Membiasakan anak untuk melakukan refleksi dari setiap kegiatan pembelajaran yang telah dilakukan. 7) Melakukan penilaian secara objektif, yaitu menilai kemampuan yang sebenarnya pada setiap siswa(Istarani \&Ridwan, 2014).

Sebelum melaksanakan pembelajaran dengan menggunakan CTL. Secara garis besar langkah-langkah penerapan CTL dalam kelas adalah sebagai berikut: 1) Kembangkan pemikiran bahwa anak akan belajar lebih bermakna jika cara bekerja sendiri, menemukan sendiri, dan mengkontruksi sendiri pengetahuan dan keterampilan barunya. 2) Laksanakan kegiatan inkuiri (menemukan) untuk semua topik. 3) Kembangkan sifat ingin tahu siswa dengan bertanya. 4)Ciptakan masyarakat belajar (belajar kelompok-kelompok). 5) Hadirkan model sebagai media pembelajaran. 6) Melakukan refleksi di akhir pertemuan. 7) Lakukan penilaian yang sebenarnya dari berbagai sumber dan dengan berbagai cara (Nurhadi, 2004).

Tabel 1: Fase-Fase Model Pembelajaran CTL

\begin{tabular}{ll}
\hline No & Jenis Aktivitas Guru \\
\hline 1 & Guru menjelaskan materi yang akan dipelajari dan memerintahkan masing-masing \\
& siswa duduk secara berkelompok yang telah dibagikan sebelumnya secara heterogen \\
& dan membagi LKS Pada masing-masing kelompok.
\end{tabular}

2 Guru mengajukan permasalahan kontekstual yang terdapat dalam LKS yang berhubungan dengan tujuan pembelajaran. (Contruktivisme)

3 Guru membimbing dan mengarahkan siswa untuk mengkomunikasikan permasalahan melalui tanya jawab dan diskusi disini guru mengutamakan bagi siswa yang kurang aktif pada pertemuan sebelumnya (Learning Community dan Qusetioning)

4 Setelah siswa mengkomunikasikan permasalahan yang diajukan, guru memerintah tiap kelompok untuk melakukan kegiatan siswa yang ada dalam LKS.

5 Guru mengarahkan dan membimbing setiap kelompok menemukan keliling dan luas bangun segi empat dengan melakukan tanya jawab dan diskusi.

6 Guru mengarahkan dan membimbing setiap kelompok untuk menemukan solusi dan membuat model matematika dari permasalahan yang diberikan

7 Guru memerintahkan agar setiap individu di dalam kelompok berbagi pengetahuan dengan anggota yang lain.

Dengan harapan agar siswa yang pintar dapat membantu siswa yang lemah.

8. Perwakilan kelompok menyajikan model matematis, solusi, dan komunikasi permasalahan di depan kelas dan kelompok lain memberi tanggapan.

9. Guru dan siswa menyimpulkan materi secara umum dari klasrifikasi temuan setiap kelompok (Reflecting)

10. Guru memberikan kesempatan pada siswa untuk bertanya tentang materi yang belum mengerti kemudian guru mengulangi konsep yang sukar dipahami siswa. 
Model pembelajaran CTL memiliki kelebihan dan kekurangan yaitu: 1) Dapat mengembangkan pemikiran siswa untuk melakukan kegiatan belajar bermakna. 2) Siswa dapat belajar sendiri dan menemukan sendiri serta mengkonstruksikan sendiri pengetahuan dan keterampilan baru yang dimilikinya. 3) Dapat melaksanakan sejauh mungkin kegiatan Inquiry untuk semua topik yang diajarkan. 4) Dapat mengembangkan sifat ingin tahu siswa melalui memunculkan pertanyaan-pertanyan. 5) Menciptakan masyarakat belajar seperti melalui kegiatan kelompok berdiskusi, tanya jawab, dan lain sebagainya. 6) Menghadirkan model sebagai contoh pembelajaran, bisa melalui ilustrasi, model, bahkan media yang sebenarnya. 7) Membiasakan anak untuk melakukan refleksi dari setiap kegiatan pembelajaran yang telah dilakukan. 8) Melakukan penilaian secara objektf, yaitu menilai kemampuan yang sebenarnya pada siswa. 9) Dapat menemukan hal-hal yang baru dari hasil pembelajaran (Istarani \& Ridwan, 2014).

Model ini nyaris tidak memiliki kelemahan dalam pelaksanaannya. Namun yang namanya model pasti ada kelemahannya, yaitu: 1) Bagi siswa yang lambat dalam berfikir akan sulit untuk mengikuti pola pembelajaran seperti ini. 2) Guru harus terlebih dahulu memahami materi secara luas dan mendalam, karena bisa saja ada temuan baru dari siswa ketika proses belajar. Jadi, kalau guru tidak paham betul, maka akan terjadi kekeliruan dalam menentukan hasil belajar.

Adapun cara yang dilakukan peneliti untuk meminimalisir kekurangan, sebagai berikut: 1) Membagi siswa menjadi 5 kelompok yang heterogen, dengan tujuan agar siswa yang pintar bisa membantu dan berbagi ilmu dengan siswa yang lambat dalam berfikir. 2) Guru akan memahami secara dalam materi yang akan di ajarkan dan mencari terlebih dahulu materi secara luas.

\section{METODE}

Populasi dalam penelitian ini adalah seluruh siswa MTs Islamic Centre Al-Hidayah Kampar tahun pelajaran 2016/2017 yang berjumlah 384 orang yang tersebar dalam Tujuh belas kelas, yang merupakan populasi umumnya. Sedangkan populasi targetnya adalah seluruh siswa kelas VII di MTs Islamic Centre Al-Hidayah Kampar sebanyak 164 siswa yang terdiri 6 kelas yaitu kelas VII.1, VII.2, VII.3, VII.4, VII.5 dan VII.6.

Pemilihan Sekolah ini berdasarkan pertimbangan di sekolah ini memiliki permasalahan kemampuan komunikasi matematis siswa, sehingga dipandang sesuai sebagai tempat pelaksanaan penelitian. Penelitian dilakukan dikelas VII karena pokok bahasan yang dijadikan bahan ajar dalam penelitian ini adalah materi kelas VII semester 2, sehingga tidak mungkin mengambil populasi kelas VIII dan IX. Pengambilan sampel dilakukan secara "Cluster Random Sampling" yaitu teknik pengambilan sampel secara acak. Dari seluruh kelas VII yang ada kemudian dipilih 2 kelas untuk dijadikan sampel penelitian. Dari dua kelas yang terambil, kelas VII-1 dijadikan sebagai kelas kontrol dan kelas VII-3 sebagai kelas eksperimen.

Berdasarkan permasalahan yang dikemukakan sebelumnya dan tujuan yang ingin dicapai, maka jenis penelitian ini adalah eksperimen semu (Quasi Eksperimen). Dalam desain ini terdapat dua kelompok yang dipilih secara langsung. Kelompok pertama diberi perlakuan (X) dan kelompok yang lain tidak. kelompok yang diberi perlakuan disebut kelompok eksperimen dan kelompok yang tidak diberi perlakuan disebut kelompok kontrol.

Penelitian ini menggunakan dua cara pengumpulan data yaitu dengan tes soal berupa tes awal PAM dan tes akhir (post-test). Tes soal dilakukan sebelum dan sesudah pelaksanaan pembelajaran pada kelas eksperimen mendapatkan model pembelajaran CTL dan kelas kontrol dengan pembelajaran langsung. 


\section{HASIL}

Sesuai dengan rumusan masalah penelitian, maka teknik yang digunakan dalam menganalisis data untuk menguji hipotesis 1,2, menggunakan uji t jika datanya berdistribusi normal dan homogenya dan $t^{\prime}$ jika tidak homogen. Sedangkan jika tidak berdistribusi normal, pengujiannya hipotesis langsung dengan uji nonparametric yaitu Mann Whitney U. Tujuan dari uji ini adalah untuk mengetahui apakah komunikasi matematis siswa kelas eksperimen lebih baik dari rata-rata hasil komunikasi matematis kelas kontrol. Uji yang dilakukan dengan kriteria jika nilai signifikan yang diperoleh lebih kecil dari 0,05 maka $_{1}$ diterima, jika nilai signifikan yang diperoleh lebih besar dari 0,05 maka $\mathrm{H}_{0}$ diterima. Untuk hipotesis ke 3 menggunakan uji korelasi. Dan untuk menguji hipotesis 4 menggunakan anova dua arah.

1. Terdapat atau tidak perbedaan kemampuan komunikasi matematis antara siswa yang mengikuti pembelajaran dengan model pembelajaran CTL dengan siswa yang mengikuti pembelajaran langsung.

Tabel 3. Uji “t” Post-Test

\begin{tabular}{ccc}
\hline$t_{\text {hitung }}$ & $t_{\text {tabel }} 5 \%$ & Keterangan \\
\hline 3,065 & 1,67 & Ha diterima \\
\hline
\end{tabular}

Pada tabel 3, dapat dilihat dari Dengan $t_{\text {hitung }}=3,065$ berarti besar $t_{\text {hitung }}$ dibandingkan $t_{\text {tabel }}$ pada taraf signifikan 5\% adalah 3,065 >1,67 atau $t_{\text {hitung }}>t_{\text {tabel }}$, maka $H_{a}$ diterima dan $H_{o}$ ditolak. Dengan demikian dapat disimpulkan terdapat perbedaan kemampuan komunikasi matematis antara siswa yang mengikuti pembelajaran dengan model pembelajaran CTL dengan siswa yang mengikuti pembelajaran langsung.

2. Terdapat atau tidak perbedaan pengetahuan awal siswa kelas eksperimen dan kelas kontrol.

Tabel 4.Uji “t” PAM

\begin{tabular}{ccl}
\hline$t_{\text {hitung }}$ & $t_{\text {tabel }} 5 \%$ & Keterangan \\
\hline 0,15 & 1,67 & $\mathrm{H}_{\mathrm{o}}$ diterima \\
\hline
\end{tabular}

Berdasarkan Tabel 4, dapat dilihat dari nilai $t_{\text {hitung }} 0,15$ dan $t_{\text {tabel }}$ 1,67 pada taraf signifikan 5\%. Maka nilai $t_{\text {hitung }} \leq \mathrm{t}_{\text {tabel }}$ yang berarti $\mathrm{H}_{\mathrm{a}}$ ditolak dan $\mathrm{H}_{\mathrm{o}}$ diterima, dengan demikian dapat disimpulkan bahwa tidak perbedaan pengetahuan awal siswa kelas eksperimen dan kelas control.

3. Ada atau tidaknya kontribusi yang di berikan PAM terhadap kemampuan komunikasi matematis siswa kelas eksperimen.

Tabel 5. Uji Korelasi

\begin{tabular}{ccl}
\hline$r_{x y}$ & $K P$ & Keterangan \\
\hline 0,96 & $92,16 \%$ & Sangat Kuat \\
\hline
\end{tabular}

Hal ini dapat dilihat dari nilai $\mathrm{r}_{\mathrm{xy}} 92,16 \%$ dan sisanya $7,84 \%$ di tentukan oleh variabel lain. Dengan demikian dapat simpulkan bahwa Adanya kontribusi yang sangat kuat yang di berikan PAM terhadap kemampuan komunikasi matematis siswa kelas eksperimen. 
4. Terdapat atau Tidaknya interaksi antara metode pembelajaran ditinjau dari pengetahuan awal siswa terhadap kemampuan komunikasi matematis.

Tabel 6. Hasil Uji Anova

\begin{tabular}{lrrrrr}
\hline \multicolumn{1}{c}{ Sumber Variansi } & Dk & \multicolumn{1}{c}{ JK } & \multicolumn{1}{c}{ RK } & \multicolumn{1}{c}{ Fh } & Fk \\
\hline Antar kolom (KAM) & 2 & 7367 & 3683 & 268 & 3,17 \\
Antar baris (Model) & 1 & 1401,6 & 2368,1 & 6224,1 & 1,02 \\
Interaksi KAM*Model & 2 & $-314,5$ & $-157,2$ & $-265,7$ & 3,17 \\
\hline
\end{tabular}

Berdasarkan tabel dapat disimpulkan bahwa Faktor model pembelajaran memberikan pengaruh yang signifikan terhadap komunikasi matematis. Hal ini terlihat dari nilai signifikan untuk model pembelajaran adalah 6224,106. Faktor PAM juga memberikan pengaruh yang signifikan terhadap komunikasi matematis. Hal ini terlihat dari nilai signifikan untuk PAM adalah 2368,132. Untuk melihat ada atau tidak nya interaksi antara model pembelajaran dan PAM siswa terhadap komunikasi matematis, kriteria pengujian adalah jika signifikan $\mathrm{Fh}>\mathrm{Fk}$ maka hipotesis diterima.

Tabel diatas memperlihatkan nilai Fh yang diperoleh adalah -265,731 dengan Fk 3,17. Hal ini berarti hipotesis yang menyatakan $\mathrm{H}_{0}$ diterima, artinya tidak terdapat interaksi antara model pembelajaran dan PAM. Dengan kata lain komunikasi matematis siswa karena pengaruh model pembelajaran tidak bergantung pada peringkat PAM siswa, dan komunikasi siswa karena pengaruh peringkat PAM tidak bergantung pada penggunaan model pembelajaran. Dengan demikian analisis pasca Anova tidak dilanjutkan.

\section{PEMBAHASAN}

Berdasarkan hasil yang dipaparkan sebelumna, dapat dilihat adanya perbedaan kemampuan komunikasi matematis siswa antara siswa yang menggunakan pembelajaran CTL dengan siswa yang menggunakan pembelajaran langsung. Lebih lengkapnya bahwa hasil pengujian memperoleh temuan bahwa terdapat perbedaan kemampuan komunikasi matematis antara siswa yang mengikuti pembelajaran dengan model pembelajaran CTL dengan siswa yang mengikuti pembelajaran langsung. Hasil dari peritungan uji-t diperoleh $t_{\text {hitung }}=3,065$ berarti besar $t_{\text {hitung }}$ dibandingkan $\mathrm{t}_{\text {tabel }}$ pada taraf signifikan $5 \%$ adalah 3,065>1,67 atau $\mathrm{t}_{\text {hitung }}>\mathrm{t}_{\text {tabel }}$, maka $\mathrm{H}_{\mathrm{a}}$ diterima dan $\mathrm{H}_{\mathrm{o}}$ ditolak.

Tidak Terdapat perbedaan pengetahuan awal siswa kelas eksperimen dan kelas kontrol. Hasil dari peritungan uji-t diperoleh $t_{\text {hitung }} 0,15$ dan $t_{\text {tabel }} 1,67$ pada taraf signifikan $5 \%$. Maka nilai $\mathrm{t}_{\text {hitung }} \leq \mathrm{t}_{\text {tabel }}$ yang berarti $\mathrm{H}_{\mathrm{a}}$ ditolak dan $\mathrm{H}_{\mathrm{o}}$ diterima.

Terdapat kontribusi yang di berikan PAM terhadap kemampuan komunikasi matematis siswa. Hasil dari peritungan uji-korelasi diperoleh nilai $r_{x y} 92,16 \%$ dan sisanya $7,84 \%$ di tentukan oleh variabel lain.

Tidak terdapat interaksi model pembelajaran dan PAM. Dengan kata lain kemampuan komunikasi matematis siswa karena pengaruh model pembelajaran tidak bergantung pada peringkat PAM siswa dan komunikasi siswa karna pengaruh peringkat PAM tidak bergantung pada model pembelajaran. Hasil dari peritungan Anova dua arah diperoleh nilai $\mathrm{Fh}$ yang diperoleh adalah -265,731 dengan Fk 3,17. Hal ini berarti hipotesis yang menyatakan $\mathrm{H}_{0}$ diterima, artinya tidak terdapat interaksi antara model pembelajaran dan PAM.

Jadi, sdapat disimpulkan bahwa terdapat pengaruh penerapan model pembelajaran CTL terhadap kemampuan komunikasi Matematis ditinjau dari Pengetahuan awal matematis siswa. Selanjutnya, peneliti dapat merekomendasikan model pembelajaran CTL dapat dijadikan salah satu 
alternatif strategi pembelajaran pada mata pelajaran matematika. diharapkan kepada peneliti selanjutnya supaya membuat soal dengan tingkat kesukaran tinggi, sedang, dan mudah. Pada saat penerapkan model pembelajaran CTL ini, masih ada siswa yang kurang aktif dalam melaksanakan diskusi. Diharapkan kepada guru agar bisa mengontrol siswa secara maksimal pada saat diskusi berlangsung.

\section{PENGHARGAAN}

Ucapapan terima kasih kepada semua yang telah membantu dalam menyelesaikan penyelesaian ini.

\section{REFERENSI}

Ansari B. L. (2016). Komunikasi Matematik: Strategi Berfikir dan Manajemen Belajar. Banda Aceh: Pena

Cai J., Jakabscin M. S., \& Lane, S. (1996). Assesing Students' Mathematical Communication. School Science and Mathematics. 96 (5). 238 - 246.

Cangara, H. (2005). Pengantar Ilmu Komunikasi, Jakarta:PT RajaGrafindo Persada

Dewi, P., Asnawati, R., \& Widyastuti. (2017). Penerapan Strategi REACT untuk Meningkatkan Kemampuan Komunikasi MatematisSiswa. Jurnal Pendidikan Matematika Unila, 5(3) retrieved from: http://jurnal.fkip.unila.ac.id/index.php/MTK/article/view/12418

Gardenia, N. (2016). Peningkatan Kemampuan Pemahaman dan Komunikasi Matematis Siswa SMP Melalui Pembelajaran Konsstruktivisme Model Needham. Jurnal Formatif, 6(2), 110 118.

Hanapi, G. R., Hulukati, E., \& Gani, U. (2013), Pengaruh Pendekatan Contextual Teaching Learning Terhadap Kemampuan Komunikasi Matematika Siswa SMP Negeri 1 Kabila. Jurnal KIM FMIPA. 1(1). Diakses dari: http://kim.ung.ac.id/ index.php/KIMFMIPA/ issue/view/79

Harun, L. (2012). Eksperimentasi Pembelajaran Matematika Dengan Pendekatan CTL Ditinjau Dari Pengetahuan awal Siswa Kelas Vii Smp Negeri Kabupaten Sukoharjo. Jurnal Ilmiah Matematika dan Pendidikan Matematika, 4(1), 197-206.

Istarani, \& Ridwan, M. (2014). 50 Tipe Pembelajaran Kooperatif, Medan: CV ISCOM

Majid, A. (2008). Perencanaan Pembelajaran. Bandung: Remaja Rosdakarya

Mahmudi, A. (2009). Komunikasi dalam pembelajaran matematika. Jurnal MIP MIPA UNHALU. 8(1), diakses: http://staffnew.uny.ac.id/upload/132240454/penelitian/Makalah+06+Jurnal+ UNHALU+2008+_Komunikasi+dlm+Pembelajaran+Matematika_.pdf

Nurhadi. Yasin, B. \& Senduk, A.G. (2004). Pembelajaran Kontekstual dan penerapannya dalam KBK. Malang, Indonesia: Penerbit Universitas Negeri Malang.

Risnawati. (2008). Strategi Pembelajaran Matematik. Pekanbaru: Suska Press

Sanjaya, W. (2010). Strategi Pembelajaran Berorientasi Standar Proses Pendidikan. Jakarta: Kencana

Sefalianti, B. (2014). Pengaruh Pendektan Inkuiri Terbimbing terhadap Kemampuan komunikasi dan Disposisi Matematis Siswa. Jurnal Pendidikan dan Keguruan, 1(2), 11-20

Supriyanto, A. (2014). Penguatan Kemampuan KomunikasiMatematis sebagai Landasan Menumbubkan Motivasi Belajar siswa. prosiding Seminar Nasional Pendidikan Matematika Program Pasca Sarjana Volume I Bandung: STKIP Siliwangi 
Sumarmo, U. (2013). Berfikir dan Diposisi Matematika Serta Pembelajarannya. Bandung: FMIPA UPI

Syah, M. (2004). Psikologi Pendidikan dengan Pendekatan Baru (Edisi 10). Bandung, Indonesia: Remaja Rosdakarya

TIMSS, (2011). International Result in Mathematics. http://timssandpirls.bc.edu/timss2011/ download/TII-IR-Matematics-FullBokk. Diakses pada tanggal 06 juni 2017 pukul 08.30.

Trianto. (2009). Mendesain Model Pembelajaran Inovatif-Progresif. Jakarta: Kencana Prenada Media Group.

Zein, M \& Darto. (2012). Evaluasi Pembelajaran Matematika. Pekanbaru, Indonesia: Daulat Riau 